\title{
The techniques of Translation Into Original Film Subtitles (Aladdin 2019: A Whole New World) in English Into Indonesian
}

\author{
Rika Pidia $^{1 *}$, Tahrun $^{2}$, Mulyadi $^{2}$
}

\author{
${ }^{1}$ SMP Negeri 1 Betung \\ ${ }^{2}$ Univerisitas PGRI Palembang \\ *Corresponding author. Email: rika.pidia1978@gmail.com,
}

\begin{abstract}
The goal of the research (1) is to identify the kinds of translation techniques that the translator applies in the translation of song lyrics; (2) how the consistency and accuracy of the quality are represented the details were song lyrics of the Aladdin film 2019: www.subscene.com's "A Whole New World." The other information was collected from the two raters evaluated questionnaires. In the film, there were 189 data for the total song lyrics. The translation techniques' outcome indicates that the translator implemented six techniques in song lyrics in the Aladdin film 2019: "A Whole New World" from www.Subscane.com, technical literal124numbers. "The whole new world." 33-number modulation, 17-number reduction, 9-number equivalent development, 3-number borrowing, general 3-number generalization Translation precision with 162 has been shown to lease precise translation with 23-number inaccurate 4number. The outcome was 146 acceptable numbers, less acceptable with 34 numbers and 9 inadmissible numbers. Seen from www.subscane.com translation quality it was valid, 162 numbers and 146 numbers were appropriate. One could infer that www.subscane.com had a high quality subtitle.
\end{abstract}

Keywords: Translation, Technique, Quality

\section{INTRODUCTION}

Translation is a mechanism by which messages are translated into a particular language that is Transformed into other languages so that readers who understand the target language can understand it. Often it is difficult for individuals to grasp the content of Western films that use English. Translation is also necessary for the production of films with subtitles. Translation refers to information printed, whereas interpretation refers to information spoken [1]. The translation is generally used to translate the written or oral text resource in the oral or written text or language of an analogous aim. A source language is the language in which the content to be translated/interpreted was initially produced ; for instance it may be a document text or a speech. The language in which the material is for translation is a target language / interpretation will be reproduced into; going with the same example above the text or speech. The main goal of a film's translation is to get the public to appreciate the author's message and facts [2].
The result was a direct effect of globalization on the manufacture of translation studies. Translation studies act as a bridge to avoid communication divisions, as the planet is experiencing fast communication and agility acceleration. Newmark [3] noted that the translation law takes account of the basic functional context of the source language in a target language. It passes the significance of a text to the translator. He uses his creativity to understand the notion of the original language in the target language. More than that, when the trader must introduce in other languages the new word element. The culture which has evolved for a long time often influences the language of every country. Translation is an important phenomenon that has an enormous effect on daily life. English as the most significant second language to be spoken by people all over the worldThe role of the translators is important since the two languages are related. Bell [4] observed that the purpose of translation theory is not to include a collection of conditions to achieve perfect traduction as is often generally misinterpreted but to explain the processes conducted throughout the translation act. Subtitling was one of the best works of translation [5]. 
Many publishers, such as magazines, newspapers, books, film subtitles or poetry, have collaborated with translators. This is because most records are not in the language where other people understand. The job of translation has become what we know is English, the foreign language. The English language of each publication was translated. Indonesia must also consider the transition from the source into the target tongue, as a nation that does not use english as the main language. The work of the translators is necessary because people who learn English need the idea of translating the source language into the target language.

Translation has many definitions and is characterized in many ways. Translation translates a message from the source to the target language (TL) (SL). The second is a process which involves two senses of translation. This means immediately that the term translation protects many alternative views. In the first sense, the trader's job is to enter a text in another language into the original or source text (ST) (target text, TT). The second meaning depends on the specific commodity the translator produces. Responding to Newmark [3], the context of a text is made by translation. This implies that translation moves the meaning of the author to another language.

Translation is characterized by linguistics in various ways. They usually have the same principle of making a simple meaning of translation. According to Newmark [3] "Translation is rendering the meaning of a text into another language in the way that the author intended the text." Due to a variety of reasons, translation often requires certain forms of loss of context. Therefore a successful translation is seen not only through language shifts, but also through the transfer of meaning.

Translation is an operation transferred writing text messages from one language to another. This is called Source Text (ST) and the Source Language (SL) in the text translated. Minimal translation requires two languages, according to Catford [6]. In addition, the Catford translation consists of a single language translation of text content and textual material into another language. textual material (the target language). It also refers to the fact that the form in the root language is substituted by language targets or target language types in the redirection forms. Not only shifts in language show a successful translation but also the transmission of significance [7].

The intrinsic factor then focuses all the stories in movie are elements of the book which are not part of the plot of the movie [8]. The intrinsic elements for analyzing fiction work are subjects, drawings, characteristics, contexts, viewpoints, and language [9].

\section{METHODS}

This study employs qualitative techniques of analysis. Qualitative analysis is research that does not use statistical equations, statistics or computer (including historical and descriptive research). Only data is collected, classified, analysed and checked by the researcher. The investigator qualitatively analyzes the localization technique. The purpose of this investigation is the form of techniques of translation. In this review, data collection is performed in three strategic phased steps, i.e. the data collection stage, data processing phase and data analysis phase.

\section{RESULTS AND DISCUSSION}

The first discussion will be on the analysis of the translation techniques used by the translators. The translation technique or translation technique is actually a collection of several ways to translate a sentence or word at a micro level. It means that the translation technique covers the smallest things in a reading text what is the smallest and smallest part of the reading? According to the sentence, the small part of the text is the smallest part of the text is the word. In other words, translation techniques are tools or methods used to translate sentences or words in a reading text. Then how the translation techniques are applied in translating the original soundtrack movie Aladdin 2019 : A Whole New World. There are 18 translation techniques. There are eighteen techniques for translation from Molina \& Albir , which are:

\section{Adaptation}

This adaptation has the meaning of taking. However, according to Molina \& Albir's theory, adaptation is a technique used specifically for words that have cultural values or those that have cultural elements. Because this technique translates sentences that are adapted to cultural elements. All the things included in customs, habits, and behavior in the source language and the target language. Thus, a word cannot actually be converted into the target language in the source language Since the term in the source language doesn't actually have a target language counterpart. For instance:

\section{Amplification}

\begin{tabular}{|r|l|}
\hline SL & Sonofia slut, bitch \\
\hline TL & Brengsek \\
\hline
\end{tabular}

Enlargement is a technique of translation by adding a little additional information in the target language, but not changing the message from the source language. Example: 


\begin{tabular}{|r|l|}
\hline SL & $\begin{array}{l}\text { This Indonesian food is very tasty pecel } \\
\text { rice. }\end{array}$ \\
\hline TL & Nasi pecel sangat enak \\
\hline
\end{tabular}

\section{Borrowing}

The borrowing technique is a technique Borrowing of root language vocabulary and translating "borrowing" into the target language. Two kinds of loans exist, namely:

a) Crediting pure

Capitalization implies an expression borrowing technique without changing anything from the source language.

\begin{tabular}{|r|r|}
\hline SL & sandwich \\
\hline TL & sandwich \\
\hline
\end{tabular}

For example, the word sandwich in English is translated exactly as sandwich in Bahasa Indonesia. One of the factors in using this technique is the absence of an appropriate goal language parallel. Then in the root terms language are taken directly as a result of translation in the target language.

\section{b) Naturalized Borrowing}

This naturalized borrowing technique takes words from the target language, but by adjusting the sound, writing or pronunciation of words in the language of goal.

\begin{tabular}{|c|c|}
\hline SL & Group \\
\hline TL & Group \\
\hline
\end{tabular}

For instance, the word GROUP. In English, the word group has five words, namely group. This word was then taken and used as Indonesian by changing the writing of the word group. Thus, in Indonesian it is sufficient to write using four letters, namely groups with the same meaning. In this case, naturalized borrowing is carried out on word writing. In this example statement, naturalized borrowings are intended to generate the appearance that the term of the source language of the target language appears more naturally.

\section{Calque}

This approach is close to the method of borrowing. The equation is, both the calque and borrowing techniques translate words by translating their lexical and structural elements. The lexical element means the real meaning of the word. The main characteristic of the Calque technique is that it can translate words or phrases (phrases). Meanwhile, the borrowing technique can only translate words. For instance:

\begin{tabular}{|c|c|}
\hline SL & General Assistant \\
\hline TL & Assistant General \\
\hline
\end{tabular}

Two important points characterize the Calque technique, namely:

a) Calque technique can translate words and phrases.

b) The calque technique may retain the lexical element of a word, but in the result of its translation the calque technique adjust the word structure in the target language.

\section{Compensation}

Payment is a technique that preserves the style of art or the stylistic characteristic of the scientific language. For instance:

\begin{tabular}{|l|l|}
\hline \multicolumn{1}{|c|}{ Source Language } & \multicolumn{1}{|c|}{ Target Language } \\
\hline $\begin{array}{l}\text { If there is a place you`ve } \\
\text { got to go } \\
\text { I'm the one you need to } \\
\text { know } \\
\begin{array}{l}\text { If there is a place you 've } \\
\text { got to get }\end{array}\end{array}$ & $\begin{array}{l}\text { Akulah orang yang } \\
\text { tepat, } \\
\text { Jika kau mencari } \\
\text { lokasi, } \\
\text { I can get you there, I bet } \\
\text { Akulah orang yang kau } \\
\text { cari, }\end{array}$ \\
\hline
\end{tabular}

Source and target language have in common one thing, the poetry of the expression, which is not at all lost. Just look at the two columns, every word that ends in the same, I've given a thick mark.

Therefore, translating a text with this compensation technique is not that easy. I admit, this one who translates Dora's song is one of the top translator. In meaning, the diction taken, and even the form of the text in the source language does not change.

\section{Description}

Description is a translation technique that uses the addition of an explanation in its translation. Therefore, it is not uncommon for this technique's translation results to usually not look like the translation. For instance:

\begin{tabular}{|r|l|}
\hline SL & Boxing day \\
\hline TL & $\begin{array}{l}\text { Satu hari sesudah natal dimana klub-klub } \\
\text { sepak bola liga prime Inggris masih } \\
\text { bertanding }\end{array}$ \\
\hline
\end{tabular}




\section{Discursive creation}

The discrusive creation technique is a translation technique that doesn't really "care" about the language transfer in detail. This means that discrusive creation techniques tend to translate a sentence based on another point of view. That's why, many people are often surprised when comparing the difference in book titles in English and Indonesian. Many people would say that the translation of that title is out of context for the book's title. For instance:

\begin{tabular}{|r|l|}
\hline SL & Husband for a Year \\
\hline TL & Suami sementara \\
\hline
\end{tabular}

\section{Establish equivalent}

The equivalent technique developed is a translation technique which promotes traditional or equitable translation in the target language. For instance:

\begin{tabular}{|c|c|}
\hline SL & $\begin{array}{c}\text { Whenever I see burgers my mouth gets } \\
\text { watered. }\end{array}$ \\
\hline TL & Ngiler \\
\hline
\end{tabular}

9. Generalization

Generalization technique is a translation technique used to translate specific terms into general terms. For instance:

\begin{tabular}{|c|l|}
\hline SL & $\begin{array}{l}\text { It takes us two hours by car or train to reach } \\
\text { this area. }\end{array}$ \\
\hline TL & $\begin{array}{l}\text { Kami membutuhkan waktu dua jam untuk } \\
\text { mencapai kota ini menggunakan kendaraan } \\
\text { darat. }\end{array}$ \\
\hline
\end{tabular}

The root language and the target language vary somewhat. The exception is that vehicle names are translated. As we can see, the source language mentions two vehicles, namely cars and trains. However, different things are in the translation. There is no name of the vehicle, and only land vehicles.

\section{Linguistic amplification}

Linguistic enhancement is a technique of translation that attaches a language to the translation. It's almost like a description, only if the addition of the technique description only serves to explain a term into the target language. But here, linguistic amplification is different. For instance:

\begin{tabular}{|r|l|}
\hline SL & $\begin{array}{l}\text { That dolphin comes out and jump over } \\
\text { the fire hole. }\end{array}$ \\
\hline TL & $\begin{array}{c}\text { Lumba-lumba itu keluar dari air dan } \\
\text { melompat melewati lingkaran api. }\end{array}$ \\
\hline
\end{tabular}

\section{Linguistic compression}

The technique of linguistic compression is a translation technique which reduces a sentence's language aspect. This method is usually used to translate or dubb. The reduction of the linguistic element in a sentence using this technique aims to cut or shorten the duration of the pronunciation of a sentence, so that the duration is shorter. For instance:

\begin{tabular}{|c|c|}
\hline SL & This puppet will put a smile to their faces . \\
\hline TL & Boneka ini akan membuat mereka tersenyum \\
\hline
\end{tabular}

\section{Literal translation}

Literal translation is also known as a literal translation technique. It means that translation carried out using literal translation techniques will only translate words. But in a meaningful way, the message conveyed may not be conveyed. Example :

\begin{tabular}{|r|l|}
\hline ST & Killing two birds with one stone. \\
\hline TT & Membunuh dua burung dengan satu batu. \\
\hline
\end{tabular}

Look at the target language, that in addition to translating lexically, literal translation also translates words by adjusting the structure of the target language. But there is one thing missing from the sentence, namely its meaning. The sentence killing two birds with one stone is a proverb or proverb in English which means doing two jobs simultaneously. Therefore, it is not suitable if this sentence is translated using literal transalation techniques, because the message conveyed in the source language cannot be conveyed properly. If, for example, you are asked to translate the sentence, it will be more suitable to translate with adaptation techniques, so that the sentence can be translated intowhile diving drinking water.

\section{Modulation}

Modulation is a method of translation that changes our perspective or emphasis from the source language. This can be either lexical (meaning of the word) or structurally changing this perspective. If it is lexically simple, indeed, the context of the word changes. The most obvious example of systemic improvements is the transition to the active sentence in the target language of the passive voice in the source language and vice versa. 


\begin{tabular}{|c|c|c|}
\hline No. & $\begin{array}{c}\text { Source } \\
\text { Language }\end{array}$ & $\begin{array}{c}\text { Target } \\
\text { Language }\end{array}$ \\
\hline 1. & $\begin{array}{c}\text { You are going to } \\
\text { have a baby . }\end{array}$ & $\begin{array}{c}\text { Kamu akan } \\
\text { menjadi ayah. }\end{array}$ \\
\hline 2. & $\begin{array}{c}\text { My bread was } \\
\text { eaten by him. }\end{array}$ & $\begin{array}{c}\text { Dia yang } \\
\text { makan rotiku. }\end{array}$ \\
\hline
\end{tabular}

Translation of the first sentence is by changing the perspective of the sentence by changing the focus. If in the source language the main focus is - we will accept something, namely children. But in the target language, the perspective changes. The second point of view focuses more on the RESULT of having children, namely being parents. In other words, the modulation technique in this sentence is used to change the reader's point of view by changing the lexical element or meaning of the word.

The second example of the sentence is changing the passive voice to the active voice. We can see that in the source language the word structure is passive. Meanwhile, the translation is active. In other words, the modulation technique in the second example sentence is to change the structural or grammatical elements.

\section{Particularization}

The particularization technique is the opposite of generalization. So in short, particularization technique is a translation technique that translates general terms into specific terms. EXAMPLE:

\begin{tabular}{|r|l|}
\hline ST & $\begin{array}{l}\text { It took us two hours to reach this city } \\
\text { using land vehicles . }\end{array}$ \\
\hline TL & $\begin{array}{l}\text { Kami membutuhkan waktu dua jam } \\
\text { untuk mencapai kota ini menggunakan } \\
\text { kendaraan darat }\end{array}$ \\
\hline
\end{tabular}

\section{Reduction}

The next technique is the reduction technique. Actually, this technique is similar to the linguistic amplification technique. But even though they are similar, they are not the same. The equation is, these two techniques reduce one element in a sentence. But the difference between reduction techniques and linguistic amplification techniques is that reduction techniques reduce the source language information. While linguistic amplification techniques reduce linguistic elements in a sentence. For instance:

\begin{tabular}{|c|c|}
\hline SL & $\begin{array}{c}\text { Surabaya, the capital city of East Java } \\
\text { Province, is also known as city of heroes. }\end{array}$ \\
\hline TL & $\begin{array}{c}\text { Surabaya juga dikenal sebagai kota } \\
\text { pahlawan. }\end{array}$ \\
\hline
\end{tabular}

\section{Substitution}

The substitution technique is a translation technique by replacing paralinguistic elements. Example:

\begin{tabular}{|c|c|}
\hline SL & Those two Japanese bow each other. \\
\hline TL & $\begin{array}{c}\text { Kedua orang Jepang itu saling memberi } \\
\text { salam. }\end{array}$ \\
\hline
\end{tabular}

This is unique, the source language has the word bow. But in translation, the word bow does not mean the word bend, but gives greetings.

Know for ourselves, that Japanese people will bow when they meet other people. The word is translated with the meaning of the word greeting, with the aim that the target readers know that the bowing activity in the reading has a mind that is not just bowing, but more than that, namely greeting.

\section{Transposition}

The transposition technique is a translation technique that is carried out to change the grammatical structure, change the position of adjectives, or even change the plural form to singular to be adjusted or matching the structure of the target language.

Technically speaking, transposition is almost the same as Calque's technique. But the difference is, the Calque technique only translates words and phrases. Meanwhile, transposition techniques can change more than just phrases, but start from grammatical structures, change adjectives' position, or even change the plural form to singular. Example :

The first sentence, the grammar structure in the target language is changing. The word blue book translates to blue book. This change was made to adjust the grammatical elements in the target language.

The second sentence is no addition of the word that is in Indonesian. This is done to explain the adjectives and nouns contained in the target language.

\begin{tabular}{|c|c|}
\hline $\begin{array}{c}\text { Source } \\
\text { Language }\end{array}$ & Target Language \\
\hline $\begin{array}{c}\text { I have a blue } \\
\text { book }\end{array}$ & Saya punya buku biru \\
\hline $\begin{array}{c}\text { Apply to damp } \\
\text { skin and rinse off }\end{array}$ & $\begin{array}{c}\text { Gunakan pada kulit yang } \\
\text { kusam dan bilas hingga bersih }\end{array}$ \\
\hline
\end{tabular}




\section{Variation}

The technique of variety is a technique of translation for the translation of paralinguistic components, language styles, and social dialects that are on the target. Example :

\begin{tabular}{|c|c|}
\hline Source Language & Target Language \\
\hline By the way,.. & $\begin{array}{l}\text { Ngomong- } \\
\text { mgomong }\end{array}$ \\
\hline You know what ,... & Tau gak sih, \\
\hline $\begin{array}{l}\text { For } \\
\text { information,. . }\end{array}$ & Asal kalian tau, \\
\hline
\end{tabular}

\section{CONCLUSION}

The results of the data are focused on Chapter IV's data interpretation. The details from the study were drawn from Dunia Baru's lyrics of a whole new world which were evaluated on the basis of Åkerström [10], and translation processes. The results are as follows: The study results:

For the analysis of the data the researcher uses the study's characteristic characteristics are: number of sentences, syllables vs. words, word supplements, word exclusion, rhymes use, word and line reorganization, paraphrasis. But out of ten functions, the researcher uses the 7 .

\section{ACKNOWLEDGMENTS}

Our deepest gratitude goes to Teachers in SMP Negeri 1 Betung, Chancellor of Palembang PGRI University, Director of the Postgraduate Program of PGRI Palembang University and the Education Management Study Program of PGRI Palembang University, who have supported us in doing this extraordinary thing. This project is funded independently. We also want to thank our Education Management friends who helped us a lot in a short time frame to complete this project.

\section{REFERENCES}

[1] Fitria, T. N. (2020). Translation Technique of English to Indonesian Subtitle in "Crazy Rich Asian” Movie. ELS Journal on Interdisciplinary Studies on Humanities Volume 3 Issue 1.
[2] Pahamzah, J., \& Syariifah, A. (2019). Translation Techniques of Subtitling: A Case for Trolls Movie. JELTS Vol. 2 No. 2.

[3] Newmark, P. (1981). Approaches to Translation. New York: State University of New York Press.

[4] Bell, R. T. (1991). Translation and translating: theory and practice. University of California: Longman.

[5] Hastuti, E. D. (2015). An Analysis On Subtitling Strategies Of Romeo And Juliet Movie. REGISTER, Vol. 8, No. 1.

[6] Catford, J. C. (1965). A Linguistic Theory of Translation. London: Oxford University Press.

[7] Supardi, M., \& Putri, D. A. (2018). Audio-Visual Translation: Subtitling and Dubbing Technique Movie Soundtrack in Frozen: Let it Go. Buletin AlTuras: Mimbar Sejarah,Sastra,Budaya, dan Agama Vol. XXIV No.2

[8] Andari, N, W, Y. (2019). Intrinsic Elements and Moral Values in Novel Tarian Bumi Karya Oka Rusmini (2007). RETORIKA: Jurnal Ilmu Bahasa, 5(1), 40-44. doi: http://dx.doi.org/10.22225/jr.5.1.769.40-44

[9] Nurgiyantoro, B. (2015). Teori Pengkajian Fiksi. Yogyakarta: Gadjah Mada University Press.

[10] Åkerström, J. (2009). Translating Song Lyric. Sweden : Bachelor thesis of Södertörns högskola. 